\title{
An Appraisal of the Internationalisation of Higher Education in Sub-Saharan Africa
}

Sintayehu Kassaye Alemu ${ }^{1}$

$\approx$ Over the past decades, the development of the internationalisation of higher education has revised the conceptual framework of higher education, enhanced its scope, scale and importance, and transformed its world, as well as reshaping relationships between countries. More powerful universities play a central role and are suppliers of knowledge, whereas weaker institutions and systems with fewer resources and lower academic standards occupy a peripheral position and are consumers. The centre-periphery dichotomy in the internationalisation of higher education undoubtedly presents considerable challenges to the higher education institutions of the peripheries. For developing regions like Africa, higher education is an important instrument for socioeconomic development, and one of the strategies to improve and qualify higher education is internationalisation. In spite of various attempts to enhance the benefits of internationalisation, African higher education has continued to be peripheral, with relationships remaining asymmetrical, unethical and unequal. Along with some positive benefits, internationalisation has brought complicated implications and new challenges, such as the brain drain, cultural values, the commodification of higher education, the persistence of inequality between global north-south universities, and so on. The purpose of the present paper is to highlight the challenges and unintended consequences of the internationalisation of higher education, with a particular focus on Africa.

Keywords: higher education, internationalisation, centre, periphery, challenges, Sub-Saharan Africa 


\section{Presoja internacionalizacije $\mathrm{v}$ visokem šolstvu $\mathrm{v}$ podsaharski Afriki}

Sintayehu Kassaye Alemu

$\approx \mathrm{V}$ zadnjih desetletjih je razvoj internacionalizacije visokega šolstva revidiral konceptualne okvire visokega šolstva, okrepil njegov obseg in pomembnost, preoblikoval njegov svet in odnose med državami. Vplivnejše univerze pri tem igrajo osrednjo vlogo in so ponudnice znanja, medtem ko šibkejše ustanove in sistemi $\mathrm{z}$ manj sredstvi in nižjimi akademskimi standardi zavzemajo obrobno vlogo in so uporabniki tega znanja. Dihotomija centra in periferije v internacionalizaciji visokega šolstva nesporno predstavlja velik izziv ustanovam na periferiji. Za regije v razvoju, kot je Afrika, je visoko šolstvo pomemben instrument pri družbeno-ekonomskem razvoju, ena izmed strategij za izboljšanje in zvišanje kakovosti visokega šolstva pa je prav internacionalizacija. Kljub različnim poskusom, da bi povečali učinke internacionalizacije, ostaja afriško visoko šolstvo periferno, razmerja pa še vedno nesimetrična, neetična in neenakopravna. Poleg nekaterih pozitivnih učinkov je internacionalizacija prinesla tudi zapletene posledice in nove probleme, kot so: beg možganov, sprememba kulturnih vrednot, komodifikacija visokega šolstva, ohranjanje neenakosti med univerzami v razmerju severa in juga idr. Namen prispevka je, da osvetli probleme in nepredvidene posledice internacionalizacije visokega šolstva s posebnim osredinjenjem na Afriko.

Ključne besede: visoko šolstvo, internacionalizacija, osrednji izzivi, obrobni izzivi, podsaharska Afrika 


\section{Introduction}

Africa is one of the vast continents of the world, and its higher education has been connected to the Western system through the colonial bond established since the $18^{\text {th }}$ century. Higher education institutions in Africa were therefore internationalised from an earlier period.

In Europe, with the exception of Neave (1997), Scott (1998) and few others, who consider the supposed medieval origins of the internationalisation of the university as "inaccurate" and "internationalist rhetoric", scholars regard the internationalisation of higher education as being rooted to the middle ages. There is a medieval model of the internationalisation of higher education whereby students travelled in search of courses and teachers to fit to their interests, while teachers made pilgrimages to city universities, where they could obtain better leisure, friends, information and study (de Ridder-Symoens, 1992; Huang, 2007). The rationales behind the international dimension of higher education in the medieval period were the search for knowledge and exchanges of academic and social cultures.

The international aspects of higher education during the $18^{\text {th }}$ and $19^{\text {th }}$ centuries include "export of higher education systems, dissemination of research, and individual mobility of students and scholars" (de Wit, 2002). Particularly from the beginning of the $19^{\text {th }}$ century, the export of higher education systems from Europe to the rest of the world (the Americas, Asia and Africa) was carried out through colonial ties.

The internationalisation of higher education in the modern period passed through two phases (de Wit, 2002; Huang, 2013). In the first phase, some countries, such as Japan, developed a kind of Euro-American blend model of the teaching and research university, while colonies hosted branch campuses of the principal colonial metropolitan universities. Most universities in Africa are instrumental examples of this model of internationalisation. Hans de Wit (2002) has called this phase a primitive "academic colonialism" and "academic imperialism". The second phase includes research and dissemination through seminars, conferences and publications. In the interwar period, internationalisation underwent a shift towards more international cooperation and exchange in higher education. It is particularly since the 1990s, however, that it has become an increasing concern of researchers (Teichler, 1999).

The internationalisation of higher education can be understood from six major approaches: the activity approach (involving discreet activities), the competency approach (the development of skills, knowledge, attitudes and values), the ethos approach (fostering a campus-based culture of internationalisation), 
the process approach (the integration of an international dimension into teaching, research and services) (Knight, 1999), the business approach (an emphasis on student fees for income), and the market approach (stress on competition, market domination and deregulation) (Meek, 2007). Based on these approaches, the internationalisation of higher education is defined as "the process of integrating an international, intercultural or global dimension into the purpose, functions or delivery of post-secondary education" (Knight, 2003). However, due to the dynamism of its actors and rationales (economic, social, political and cultural) and the impacts of local/national traditions, the internationalisation of higher education means different things to different people; it has changed with the changing context of its driving forces, rationales, challenges/prospects, benefits, purposes, meanings and strategies (Bulfin, 2009; IAU, 2012; Zeleza, 2012).

The internationalisation of higher education benefits from the positive initiatives of collaborative projects, of cross-border educational exchange. These initiatives have contributed to the development of individuals, institutions, nations and the world at large. The benefits of internationalisation are many and varied, but the potential risks and unintended consequences are also significant. Gradually, the objective of the internationalisation of higher education - to build capacity through international cooperation projects - has faded in favour of status-building initiatives and the augmentation of revenue. Moreover, the internationalisation of higher education has caused the destruction of cultural heritage, diminished language diversity, reduced variety in academic cultures and structures, compromised quality, and even supported imperialist takeovers (Teichler, 2004; Knight, 2013). In addition, the process of internationalisation has produced disproportionate mobility flows that have resulted in a brain drain from the south, as well as the infiltration of policies, systems and models into the south (Krstic, 2012). Enders reports the sources and destinations of student mobility, which is characterised predominantly by a southnorth direction. It is this situation that has triggered the brain drain.

The vast majority of international students are from low-and-middle-income countries, and their destinations are in the richer parts of the world, with the U.S. as a major host country followed by Australia, Canada, the United Kingdom, and Western Europe. The increasing flow of academics around the world is also dominated by a South-to-North pattern, while there is significant movement between the industrialized countries and some South-to-South movement as well (Enders, 2007, p. 16). 
Moreover, the increasing emphasis of internationalisation on marketisation/revenue rather than on capacity building has directly affected quality and equality. Thus, internationalisation has further marginalised developing and emerging regions, "not by participation but by omission" (Damtew, 2014).

The purpose of the present paper is to underscore the challenges and unintended consequences of the internationalisation of higher education with a particular focus on Africa. It also aims to enhance the current debate on the benefits, values and purposes of the internationalisation of higher education. The paper has been prepared on the basis of a qualitative review of the existing literature and public sources. It is comprised of seven sub-sections. The first section deals with the context of internationalisation, followed by the research landscape, the scenario of curriculum design and language, the nature of academic mobility, some other risks, and current debates on internationalisation in Africa. It closes with concluding remarks and some research issues.

\section{The Internationalisation of Higher Education in Sub- Saharan Africa}

\section{The Context}

Africa is the second largest and second most populous continent on earth, with an estimated population of 1.033 billion people in $2013 .{ }^{2}$ The population is projected to be 1.2 billion and 2 billion by 2025 and 2050 , respectively (AFIDEP, 2012). Economically, it is highly dependent on agriculture, which employs $60 \%$ of the region's workforce (Teklu, 2008).

Paradoxically, higher education systems in Africa are the most globally marginalised as well as being the most internationalised in their model, dimension and scope (Damtew, 2012). The internationalisation aspect of higher education dates back to the period of colonialism, when colonial systems and models replaced/aborted traditional and indigenous higher learning institutions in Africa. Damtew and Greljn have analysed the challenges and scenario under which developing countries have joined the phenomena of globalisation.

With a host of poorly developed knowledge systems, Africa is having to deal with globalization not from a position of strength, but from one enmeshed in weaknesses that have arisen from the confluence of many factors-historical, economic, educational, financial and paradigmatic. That makes it all the more difficult and more complicated for African countries to address the challenges of globalization (Damtew \& Greljn, 2010, p. 2).

2 http://worldpopulationreview.com/continents/africa-population/ 
Universities in Africa have a strong desire to internationalise, with the aim of strengthening and consolidating their potential in teaching, research, scholarship and innovation. Internationalisation is characterised by bilateral partnerships, policy/model imports, invitations to Western technical advisers, student mobility, and so on. Bilateral collaborations are driven by international agents, aid providers and institutions. Such collaborations are closely linked to aid, which is condition laden and has a strong impact on national policies and systems, as well as on academics. The position of Africa is such that it is not even able to apply the principle "scan globally-reinvent locally" (Damtew \& Greljn, 2010).

As Knight has observed, the "original goal [of internationalisation] of helping developing country students to complete a degree in another country and then return home to contribute to national development is fading fast as nations compete in the $21^{\text {st }}$ century brain race" $(2013$, p. 4 ). The truth is that most students and academics who travel abroad for education never return home. Internationalisation is considered as the new mode of imperialism, due to the recruitment of the best brains for "brain power" and the injection of systems, policies, experiences and the like. International education has become a phenomena of the rich (Sichone, 2006; Teichler, 2004; Knight, 2013).

Although it is difficult to generalise regarding the higher education environment in Africa, some common situations enable us to demonstrate the general trends, particularly in the internationalisation of higher education: firstly, Africa represents a developing political economy; secondly, Africa stands as a periphery in the centre-periphery dichotomy of higher education; thirdly, Africa views the internationalisation partnership as asymmetrical and as belonging, in the typology of Teichler (2004), to "would-be internationalisation", which refers to academics and institutions that want to be involved in internationalisation but face obstacles in being considered on equal terms; fourthly, the brain drain is a problem for most African countries, making them more vulnerable; fifthly, most African institutions are marked by inadequate financial resources, considerable demand for access, the legacy of colonialism, and poor research infrastructures and systems.

Sub-Saharan higher education operates in very difficult circumstances in terms of funding, enrolment, governance, research, teaching and academic staff. From the perspective of international standards, Africa constitutes the least-developed higher education in terms of equity and quality. Africa is made up of more than 54 independent countries, ${ }^{3}$ and by 2004 there were no more

3 This number may increase soon, as a result of the endless process of proliferation; for example, Somalia has been broken into three regions. 
than 300 higher education institutions on the continent that satisfied the criteria of a university (Damtew \& Altbach, 2004; Teklu, 2008). North Africa and some countries such as Botswana, Namibia and South Africa, as well as some institutions in Uganda, such as Makerere University, perform better than the rest of Africa. In spite of the continent having the oldest university (Egypt's AlAzhar Islamic institution $)^{4}$ and claiming an ancient academic tradition, almost all African universities have adopted the Western model of the modern university. Colonialism has influenced the organisation and the instructional media of the academe; African universities are imperfect clones of the university of the colonial masters.

It is obvious that, in terms of higher education institutions, the African continent is under researched. The challenges of African higher education institutions include: a shortage of faculty and poor faculty development; poor and unstable governance, leadership and management; problems with quality and relevance; weak research and innovation capacities and facilities; financial austerity and incapacity to diversify funding resources; poor physical facilities and infrastructure; and low access and equity (Sy Habib, 2003; Damtew \& Altbach, 2004; Sichone, 2006; Teichler, 2004; Knight, 2013). The difficulties of African higher education are further accentuated by the developments of globalisation and internationalisation (Sy Habib, 2003). These problems have seriously challenged the position of African higher education institutions in the internationalisation process of higher education. The challenges are interconnected, and the present paper focuses on research, curriculum, language and the mobility of academics.

\section{Research}

Research is an important aspect of the internationalisation of higher education. In an African university, research and dissemination is challenging and frustrating. Finding equipment and data for undertaking research is a major hurdle in most African universities; moreover, dissemination through publication and international conferences is a daunting task. The requirements of reputable Western journals, along with issues of research priorities and obtaining the required funding to participate in international conferences, are discouraging for African academics.

Africa is therefore lagging behind the rest of the world in its research productivity, which is considered a central priority in higher education and an important instrument of the knowledge economy. In 2007, for instance,

4 Ancient indigenous education institutions in Africa at all levels before the advent of colonialism include such institutions as the Al-Azhar in Cairo of 970, the Karawiyyin in Morocco of 859, the $12^{\text {th }}$ century Sankore in Timbuktu, and Ethiopian Orthodox Church schools dating from 304, to mention just a few (Teklu Abate, 2008). 
scientific research publication in Sub-Saharan Africa was at the lowest level in the world, followed by the Middle East and North Africa taken together (see Table 1). Damtew and Altbach have described the lack of infrastructure and the brain drain as the main hurdles to the development of research in Africa.

By all measures, research and publishing activities in Africa are in critical condition. The general state of research in Africa is extremely poor, and its research infrastructure is inadequate. Scarcity of laboratory equipment, chemicals, and other scientific paraphernalia; a small number of highlevel experts; poor and dilapidated libraries; alarmingly low and declining salaries of academic and research staff; a massive brain drain out of the academic institutions; the "expansion" of undergraduate education; poor oversight of research applicability; and declining, nonexistent, and unreliable sources of research funds all remain major hurdles to the development of research capacity across the continent (Damtew \& Altbach, 2004, p. 38).

Table 1. Comparison of Scientific Publications and Patent Applications by region in 2007 (Damtew \& Greljn, 2010).

\begin{tabular}{lll}
\hline Regions & Scientific Publications & Patent Applications \\
\hline East Asia and the Pacific & 14,817 & 65,506 \\
\hline Europe and Central Asia & 34,905 & 32,728 \\
\hline Latin America and the Caribbean & 10,093 & 40,003 \\
\hline South Asia & 8,896 & 2,143 \\
\hline Middle East and North Africa & 3,123 & 926 \\
\hline Sub-Saharan Africa & 3,499 & 101 \\
\hline
\end{tabular}

Table 1 clearly shows that Sub-Saharan Africa produced the least scientific research and the fewest patent applications in 2007. Europe and Central Asia have taken the lead in publication, while East Asia and the Pacific region are the frontrunners in patent application. Damtew and Altbach report the reasons behind the low level of scientific publication and patent application in Sub-Saharan Africa as follows:

The paucity of local publications is complicated by many factors, including the small number of researchers with the energy, time, funds, and support needed to sustain journals; the lack of qualified editors and editorial staff; a shortage of publishable materials; a restrictive environment that inhabits freedom of speech; and a lack of commitment to and appreciation of journal production by university administrators (Damtew \& Altbach, 2004, p. 39). 
Most universities in Africa are funded by governments and external agencies. According to the World Bank (2002), the existing research activities in Africa are largely funded (70-90\%) by external agencies, and the ramifications of such a research environment are perilous. Although research endeavours vary enormously across countries, between 1999 and 2008, African research production was mainly dominated by three countries: South Africa $(47,000)$, Egypt $(30,000)$ and Nigeria (10,000). In the same period, Central Africa, comprising 37 countries, produced 7,100 research papers per year, while Northern Africa, comprising Egypt, Tunisia, Morocco, Algeria and Sudan, generated more than 10,500 research papers in 2008 alone. The Southern region of Africa - the Republic of South Africa and more than ten other countries produced more than 10,000 papers. In total, the continent of Africa produced about 27,000 research papers per year (Adams et al., 2010).

According to University World News, most scientific papers produced by African academics are collaborative. This has stifled research individualism and affected the continent's research evolution and priorities. Collaborative research endeavours account for $66 \%$ of the continent's research over a five-year period, while single-author articles appear to be "on the verge of extinction" on the continent (University World News, 10 February 2014). Most African research papers are produced in collaboration with foreign countries, such the USA, the UK, France, Germany, Italy, Spain, Australia, Belgium, the Netherlands, China, Japan and Saudi Arabia. Most of the research issues are selected by the external collaborators and concentrate on health and agriculture programmes; for instance, Gambia and Uganda are the sites of long-term research into tropical diseases for the UK's Medical Research Council, while the Wellcome Foundation has similar major research investments in Kenya and Malawi (Adams et al., 2010). Significant intellectual benefits are thus secured outside Africa.

The internationalisation of higher education in Africa was intended "to increase the visibility of African universities in areas such as research and development, and increase the contribution that the institutions are making to the development of Africa, and open channels for Africa to benefit from the global stock of scientific knowledge" (Ogachi, 2011). There is also the promise of research networking, capacity building and the establishment of partnership. These packages may be contrary to the locally initiated process of indigenising research and innovation in African universities (Sawyerr, 2004; Ogachi, 2011; Barrnett et. al., 2014). The key challenge facing African universities in the age of internationalisation and globalisation is to explore how academic programmes can be aligned to support local and regional economic development and the eradication of poverty, as well as to promote the sustainable use of natural 
resources. Internationalisation must contribute to a situation where knowledge creation in institutions is based on Africa's research needs and priorities. However, this is not taking place in earnest.

\section{Curriculum Design and Language}

Colonial curricula supported disciplines that were inexpensive and helped colonial administration. Scientific subjects were rarely offered. This legacy continued following independence. No African country has changed the colonial higher education system or the language of instruction, a situation that is further cemented by internationalisation (Damtew \& Altbach, 2004).

In the era of internationalisation, one strategy is opening branch campuses. Some countries export domestic curricula that may not have relevance to the development strategy of the host partners, which contributes little to offshore development and internationalisation. University World News (20 April 2014) has advised partners to carefully reconsider the declared development of the domestic programme in order to address offshore cultural values and employment market needs. Internationalisation should consider the wider needs or developments of the domestic-regional employment market and of socioeconomic development. This will minimise the brain-drain effects of internationalisation activities and contribute to the longer-term prosperity of local economies.

Colonialism, globalisation and the internationalisation of higher education have made European languages - including English, French, Italian, Portuguese and Spanish - more dominant in African higher education institutions, with English becoming more prominent as a result of the internationalisation of higher education. In some African countries, there is competition between different languages for dominance in the higher education sector. In Rwanda, for instance, where English and French are officially used, there is an interesting trend towards changing the instructional medium to the vernacular language, Kinyarwanda (Ngome, 2003). There are also signs of the political preference shifting in the Sudan, in Equatorial Guinea and, to some extent, in Somalia, where perceived socioeconomic benefits appear to be dictating the choice of local languages for instruction. South Africa is discussing the future of Afrikaans as a language of higher education in a context of English domination (Ngome, 2003; Jibril, 2003; Mthembu, 2004).

Language remains a volatile social issue in many African countries. The pressure of globalisation and the internationalisation of higher education will, inter alia, continue to prevent the development of vernacular languages being used as an instructional medium in many African countries in the near future. The use and application of foreign languages as instructional media has 
made higher education institutions dependent on a knowledge system that was conceived, developed and organised on the basis of the Western context. For a number of social and political reasons, Africans are vacillatingly contemplating the use of the instructional medium and possible changes in this regard. The situation is currently unstable, which adversely affects the development of higher education institutions in Africa and jeopardises research and learning.

\section{Mobility}

In the era of the knowledge economy, skilled human resources have become a valuable prerequisite in the quest for economic growth and development. From the perspectives of globalisation and internationalisation, the purpose of mobility is "to gain different perspectives, to develop languages and global skills, to become global citizens, to be better prepared for the global workforce, and so on" (Deardorff, 2014). For Africa, education abroad is part of the academic capacity-building strategy to reconstruct the socioeconomic and political environments of the region. Most African students prefer to travel to the global north, to be enrolled as undergraduate rather than graduate students, and to study humanities and social sciences rather than natural sciences, engineering, and technology and health sciences. ${ }^{5}$ From this perspective, the contribution of internationalisation to the regional development of a knowledge-based economy is limited.

The brain drain is mostly a movement from developing countries to the most industrialised corners of the world. The internationalisation of higher education has strengthened the "opportunity" for African academics to travel abroad, and most of them remain in their foreign destination. The brain drain has jeopardised the academic institutions of developing countries, with immediate damaging effects and future consequences for the economy. Academics travel in search of better education and pay, as well as an improved working environment. It is estimated that one third of the most highly qualified Africans are living and working outside their country of origin, mostly in Western Europe and North America (World Bank, 2000). Nearly 7,0oo Kenyans with tertiary education migrated to the US in 1990, while Ghana lost around 120 doctors and more than 650 physicians in the same year (Ngome, 2003). Jibril (2003) reported that two-thirds of the 36,134 faculty positions in Nigeria are vacant, while 10,000 Nigerian academics and 21,000 physicians were working in the United States alone by 200o. South African academics are migrating to Australia, Great Britain, Canada, the United States and other developed countries (Teklu, 2008). With institutional variation, the extent of the brain drain from Ethiopian universities might be more than 50\% (Habtamu, 2003). Ethiopia

5 http://www.coursera.org/course/globalhighered 
lost about $74.6 \%$ of its human intellectual capital from various institutions between 1980 and 1991; in order to cover the vacant positions, it spends over USD 5.3 million every year in hiring expatriates (Amazan, 2014). The World Bank (2002) has estimated that some 70,000 highly qualified African professionals, experts, scholars and managers with internationally marketable skills leave Africa every year. More than 40,000 African $\mathrm{PhD}$ holders were working abroad in the 200os (Teklu, 2008).

Although the pushing factors are many and complex, and depend on the context of the specific country, one opportunity to run away from home is offered by the internationalisation of higher education (the globalised labour market). The migration of academics is not peculiar to Africa; however, considering the contemporary political economy and sociocultural environments, the effect of the brain drain is more detrimental for Africa than for the rest of the world. The academic environment (research and teaching) has been seriously affected by the internal brain drain as well: following the deterioration of the landscape of the universities, many scholars in Africa have opted for employment outside higher education institutions. Furthermore, academics often take on additional employment outside the university in order to meet their financial needs, which has seriously affected their university responsibilities of teaching, research and services (Amazan, 2014).

\section{Further Risks of Internationalisation for Africa}

According to the 2003 IAU Survey Report on the internationalisation of higher education, the number one risk for Africa is the brain drain, while the second risk is cultural identity. From the point of view of internal capacity, process and output, challenges to the benefits of the internationalisation of higher education may include: a lack of respect and equality for African universities due to the weak internal capacity (Mthembu, 2004); an increase in disparate and discrete development initiatives by isolated and unsupportive agents and projects within African institutions (Jibril, 2003; Altbach, 2004); unequal global competition to access higher education markets; the negative effects of competition on the domestic higher education market as a result of importing education from the outside world; the influx of low quality foreign providers, and so on (Teklu, 2008). Moreover, attempts to improve the internal capacity for academic and research work, thereby producing quality and world-class output, are very often frustrating and economically unrewarding.

African higher education institutions ambitiously launch plans and implementation strategies for internationalisation that demand commitment from 
top institutional leaders, faculty, students and stakeholders, and that establish monitoring processes and allocate funds from the meagre resources. However, the transformative success of the plan depends on a number of internal and external factors, such as the capacity to perform, the working system, sustainable resources, the technological capacity, and so on. Internationalisation plans are only as good as their ability to deliver transformative education to students and to promote the scholarly engagement of the faculty. Given the various and complicated problems that higher education institutions in Africa face, this is unachievable, but such plans nonetheless draw their share from the limited resources of the continent/countries, without equitable return (Habtamu, 2003; Damtew \& Altbach, 2004; Mthembu, 2004).

In addition, the internationalisation of higher education encourages higher education institutions in developing countries to carry out research and teaching at the highest international level, which heavily bench-marks the norms of large universities. This distorts academic development and introduces unrealistic expectations for institutions and for the academic profession (Altbach, 2003). Finally, in spite of an increase in knowledge, the majority of societies do not have equal access to current information and modern knowledge. This exacerbates unequal development and exchange in international education between information-rich and information-poor countries and regions, while also reinforcing the academic dominance of the global north. Every society needs to ensure the existence of viable indigenous knowledge systems, such as local institutions, structures and academics that are able to access knowledge from all sources. This may include external and home-grown, traditional and modern knowledge that is usable by local communities and agencies in local contexts (Sawyerr, 2004).

The interconnected constraints in peripheral higher education institutions, such as the lack of capacity and infrastructure in research, the brain drain, export of domestic curricula, the unsolved issues of instructional media, and the resultant unequal and unethical partnership between centres and peripheries, have triggered debates on the benefits of the internationalisation of higher education.

\section{The Current Debate: Is Internationalisation Based on Mutual Benefits?}

Current debates, ranging from concept to practice and benefits in centres and peripheries, have occupied a central place in discussions on the internationalisation of higher education. From a peripheral point of view, the 
industrialised world conception and secondment of cooperation has been for "fundraising - not from a desire for equal partnership", "profit motives", "national security interests" and "ignoring the interconnectedness of global higher education systems" (de Wit \& Jooste, 2014). Thus, internationalisation has marginalised the developing and emerging region "not by participation but by omission" (Damtew, 2014).

An international conference on "A Global Dialogue on the Future of Higher Education Internationalisation" was held in January 2014 in South Africa, organised by the International Education Association of South Africa. It was attended by 24 global education organisations from the US, Europe, Mexico, Japan, Africa, the Middle East and Latin America. The conference produced the "South African Declaration" (University World News, 23 January 2014), part of which states a "commitment to emphasizing the importance of decision-making and practices in the development of internationalisation activities that are imbued by ethical considerations of inclusivity". The declaration also includes the desire of the participants "to re-emphasize that internationalisation must be based on mutual benefits and development for entities and individuals in the developed, emerging and developing worlds". Moreover, the participants pledged "to promote international higher education and research that recognizes the richness and diversity offered by all regions for a global higher education agenda which is equitable, ethical, socially responsible, accessible and accountable". Finally, the declaration listed three integrated areas of concentration of development for the future of the internationalisation of higher education: "Enhancing aspects of quality and diversity in programs involving the mobility of students and academic and administrative staff, increasing focus on the internationalisation of the curriculum and related learning outcomes, and gaining commitment on a global basis for the creation of equal and ethical higher education partnerships." The global composition of the participants, the location of the conference, the issues raised and the resolutions passed partly manifest a powerful push from the disadvantaged group to defend their interests, while also being a vivid illustration of the shifting power relationships within global higher education and an intention to shape internationalisation in the future. 
Table 2. Summary of the academic benefits and the adverse consequences of the internationalisation of higher education.

\begin{tabular}{|c|c|}
\hline Academic Benefits (if properly practiced) & Adverse Consequences \\
\hline $\begin{array}{l}\text { Improvement in the quality of teaching, } \\
\text { learning and research. }\end{array}$ & $\begin{array}{l}\text { The gradual dominance of English may diminish the } \\
\text { evolvement of a diversity of languages studied or } \\
\text { used to deliver HE. }\end{array}$ \\
\hline $\begin{array}{l}\text { Stakeholders engage deeply in national, } \\
\text { regional and global issues. }\end{array}$ & $\begin{array}{l}\text { Global competition may adversely affect the diversi- } \\
\text { ty of institutional models and quality, and undermine } \\
\text { the HEls of developing countries. }\end{array}$ \\
\hline $\begin{array}{l}\text { Students will be better prepared as } \\
\text { national and global citizens, and as a } \\
\text { productive workforce. }\end{array}$ & $\begin{array}{l}\text { Deterioration of the capacity of HE in developing } \\
\text { countries through the brain drain. }\end{array}$ \\
\hline $\begin{array}{l}\text { Providing students with an opportunity to } \\
\text { access programmes that are unavailable } \\
\text { nationally. }\end{array}$ & $\begin{array}{l}\text { Competition may lead to unethical practices of large- } \\
\text { scale international student recruitment, which may } \\
\text { also overshadow the intellectual and intercultural } \\
\text { benefits of internationalisation. }\end{array}$ \\
\hline $\begin{array}{l}\text { Enhancing opportunities for faculty } \\
\text { improvement and decreasing the risk of } \\
\text { academic 'inbreeding'. }\end{array}$ & $\begin{array}{l}\text { Transnational campuses and distance programmes } \\
\text { would have many potential disadvantages over } \\
\text { local HEls, which are established to support national } \\
\text { socioeconomic and political needs. }\end{array}$ \\
\hline $\begin{array}{l}\text { Preparing the ground for networked } \\
\text { research. }\end{array}$ & $\begin{array}{l}\text { Reputation and ranking may force HEls and stake- } \\
\text { holders to look for partners based not on real aca- } \\
\text { demic and related interests but on the desire to gain } \\
\text { prestige by associating themselves with high-ranking } \\
\text { universities. This trend may result in exclusions. }\end{array}$ \\
\hline $\begin{array}{l}\text { Offering institutions an opportunity to } \\
\text { learn from international good practices. }\end{array}$ & $\begin{array}{l}\text { May result in asymmetrical relations that may } \\
\text { depend on the capacity of resources, and thus the } \\
\text { capacity to implement internationalisation strategies. }\end{array}$ \\
\hline $\begin{array}{l}\text { Improving institutional policy-making, } \\
\text { governance, student services, outreach, } \\
\text { quality, etc. through collaborative experi- } \\
\text { ence sharing. }\end{array}$ & $\begin{array}{l}\text { Benchmarking of large countries for internationalisa- } \\
\text { tion may pose many challenges for small/peripheral } \\
\text { countries. This may have a far-reaching effect on the } \\
\text { HEls of small countries and their academic life. }\end{array}$ \\
\hline
\end{tabular}

Source: author compilation from Damtew and Altbach, 2004; IAU, 2012; Zeleza, 2012.

\section{Conclusion}

Emphasising the challenges does not mean that Africa has not benefitted at all from the internationalisation of higher education, nor does it imply that Africa should be an island in the turbulent ocean of globalisation, which has nonetheless increased the agonies of the ill-equipped African vessels: the universities. Africa needs support and collaboration that fits its socioeconomic and cultural contexts. It can learn many things - including governance, research methodology, policy-making, technology and so on - from the international academic community and institutions, but the learning should be context-based. Africa is trying to expand higher education institutions for increased access, in order to augment the production of human capital to support the socioeconomic and cultural development efforts of the continent. The 
internationalisation of higher education mirrors Africa's position as well as its weak points. Internationalisation has benefitted student learning internally and abroad, providing students with global curricula, developing intercultural sensitivity, competence, maturity and literacy, as well as global learning, consciousness and citizenship.

At present, even though there are some advantages, the internationalisation of higher education is not benefitting developing and developed economies equally. Internal socioeconomic, cultural and political limitations; the poor "active" and "environmental" components of research; the severe impacts of the brain drain and languages; the non-contextualised adoption of alien systems, policies, and curricula; and the unequal and unethical partnership in internationalisation have made higher education institutions in Africa occupy a subaltern position, resulting in their benefitting little from the process of internationalisation. Differences in priorities of researchable issues, in infrastructures, and in access to publication have offered the north an opportunity to lead the research championship and to benefit more from internationalisation than the south. Higher education institutions and cultures of academics are strongly marked not by a philosophy and development of knowledge and strategies generated from within, but by influences coming from the north, influences that are more alienating than liberating and empowering.

The vulnerability of Africa is a result of its negligible position in the process of internationalisation and the production of knowledge. The ongoing changes in higher education around the world, as well as financial austerity, poor human capacity, the brain drain and language complexities, have seriously weakened and incapacitated many African universities in their efforts to compete with global higher education institutions. These circumstances have minimised the expected benefits from the internationalisation of higher education, while also limiting the role of higher education institutions in regional socioeconomic and cultural development.

Hence, it is imperative to push the current debate over the benefits of the internationalisation of higher education further. If the overall rationale behind the promotion of the internationalisation of higher education is global development, the global north should reconsider its "self-centred" and commercial strategies of internationalisation. This could be achieved through mutual discussion and concern.

It is important to shift internationalisation strategies towards the objective of mutual benefits through two-way communication and the adoption of a double-dip approach. In order to promote global development and enhance mutual cooperation and partnerships between stakeholders, it is necessary to 
base north-south relationships and cooperation on strong structures and sustainable frameworks that produce mutual benefits. In this respect, cooperation should be structured so as to minimise the drain of skilled individuals from Africa, and to strengthen its link with the African Diaspora to the benefit of the African continent.

Today, socially relevant and applied knowledge is more important in what is commonly referred to as the "knowledge economy". African academics should develop a sense of self-esteem. They have to be curious about both the internal and external environments, and to attempt to establish harmony between indigenous knowledge and external knowledge in order to solve internal socioeconomic problems. Without neglecting the international dimension of education, it will be imperative to promote greater freedom of regional movement for mobile students as a means of social and academic advancement and improvement. The promotion of greater pan-African cooperation and regional internationalisation, the introduction of African journals accessible to everyone, increased funding for research, the identification of regional priority research issues, an enhanced mutual and respectful approach between partners, and so on may improve the benefits of internationalisation for Africa. Moreover, the international academic community should be ready to work with higher education institutions in Africa with a conscious appreciation of the regional socioeconomic and cultural contexts. Ongoing discussion aimed at evaluating the impacts of internationalisation will also contribute to the improvement of mutual benefits. The current debate should continue with more strength and concern.

It may be helpful to conclude the discussion by indicating some issues for further research: Are the challenges and adverse consequences avoidable? If so, how? If not, what could be done to mitigate the negative impacts and challenges? Given the multifaceted adverse effects and impacts of internationalisation, to what extent do the impacted institutions need to respond to and/or tolerate the challenges? How can peripheral countries/HEIs establish a knowledge society/economy and become part of the global knowledge area?

\section{References}

Adams, J., King, C., \& Hook, D. (2010). Global Research Report: Africa. Thomson Reuters. African Institute for Development Policy (AFIDEP). (2012). Population, Climate Change, and Sustainable Development in Africa. Retrieved January 232014 from http://populationaction.org/wpcontent/uploads/2012/o6/PAI-AFIDEP.pdf Altbach, P. G. (2003). Centers and Peripheries in the Academic Profession: The Special Challenges 
of Developing Countries. In P. G. Altbach (Ed.), The Decline of the Guru: The Academic Profession in Developing and Middle-Income Countries (pp. 1-22). Palgrave Publishing

Altbach, P. G. (2004). The Past and Future of Asian Universities: Twenty-First Century Challenges. In P. G. Altbach \& T. Umakoshi (Eds.), Asian Universities-Historical Perspectives and Contemporary Challenges (pp. 13-32). Baltimore: Johns Hopkins University Press.

Amazan, R. C. (2014). When the Diaspora Returns: Analysis of Ethiopian Returnees and the Need for Highly Skilled Labour in Ethiopia. In B. Streitwieser (Ed.), Internationalisation of Higher Education and Global Mobility (pp. 169-185). Symposium Books Ltd.

Barrett, A. M., Crossley, M., \& Fon, T. P. (2014). North-South Research Partnerships in Higher Education: Perspectives from South and North. In B. Streitwieser (Ed.), Internationalisation of higher Education and Global Mobility. Symposium Books Ltd.

Bulfin, M. P. (2009). Perspectives on Higher Education in Africa: Field Notes on Trends, Themes, Challenges and Opportunities. A Journal of African Studies, 36(1), 1-9.

Damtew, T. (2014). The "Soft Power" Proof the Pudding-Not in the Branding. University World News, (308, 21 February 2014).

Damtew, T., \& Altbach, P. G. (2004). African Higher Education: Challenges for the 21st Century. Higher Education, 47, 21-50.

Damtew, T., \& Greijn, H. (2010). Introduction: Globalization and African Higher Education. In T. Damtew \& H. Greijn (Eds.), Higher Education and Globalization: Challenges, Threats and Opportunities for Africa (pp. 1-7). The Netherlands: Maastrich University Center for International Cooperation in Academic Development. de Ridder-Symoens, H. (1992). Mobility. In A History of the University in Europe, Vol. I. (pp. 28o304). Cambridge: Cambridge University Press.

Deardorff, D. K. (2014). Why Engage in Mobility? Key Issues Within Global Mobility: The Big Picture. In B. Streitwieser (Ed.), Internationalisation of Higher Education and Global Mobility (pp. 35-42). Symposium Books Ltd.

Enders, J. (2007). The Academic Profession. In J. Forest \& P. G. Altbach (Eds.), International Handbook of Higher Education (pp. 5-21). Springer.

Habtamu, W. (2003). 'Ethiopia'. In T. Damtew \& P. G. Altbach (Eds.), African Higher Education: An International Reference Handbook (pp. 316-325). Bloomington: Indiana University Press. de Wit, H. (2002). Internationalisation of Higher Education in the USA and Europe: A Historical, Comparative, and Conceptual Analysis. London: Greenwood Press.

de Wit, H., \& Jooste, N. (2014). Can International Education be Truly Equal and Global? University World News, (308, 21 February).

Huang, F. (2007). Internationalisation of Higher Education in the Era of Globalization: What have been its complications in China and Japan. Higher Education Management and Policy, 19(1), 47-61 Huang, F. (2013). The Internationalisation of the Academic Profession. In F. Huang, M. Finkelstein, \& M. Rostan (Eds.), The Internationalisation of the Academy: Changes, Realities and Prospects (pp. 1-21). Springer. 
International Association of Universities (IAU). (2012). Affirming Academic Value in Internationalisation of Higher Education: A Call for Action.

International Association of Universities (IAU). (2003). Internationalisation of Higher Education Practices and Priorities: 2003 IAU Survey Report.

Jibril, M. (2003). 'Nigeria'. In T. Damtew \& P. G. Altbach (Eds.), African Higher Education: An International Reference Handbook (pp. 492-499). Bloomington: Indiana University Press. Knight, J. (2013). The Changing Landscape of Higher Education Internationalization-for better or worse. Perspectives: Policy and Practice in Higher Education, Journal of the Association of University Administrators, (17)2, 1-11.

Knight, J. (1999). A Time of Turbulence and Transformation for Internationalization. Research monograph. No. 14. Ottawa, Canada: Canadian Bureau for International Education.

Knight, J. (2003). Updated internationalisation definition. International Higher Education, 33, 2-3. Krstic, S. (2012). Internationalisation and Competitiveness of Universities through Different Types of Researchers' Mobility-Facing the Future. In C. Adrian, P. Scott, L. Vlascean, \& L. Wilson (Eds.), European Higher Education at Crossroads. Between the Bologna Process and National Reforms (pp. 511-524). Springer.

Meek, V. L. (2007). Internationalisation of Higher Education and the Australian Academic Profession. In M. Kogan \& U. Teichler (Eds.), Key Challenges to the Academic Profession (pp. 65-80). UNESCO Forum on Higher Education Research and Knowledge.

Mthembu, T. (2004). Creating a Niche in Internationalisation for (South)African Higher Education Institutions. Journal of Studies in International Education, 8(3), 282-296.

Neave, G. (1997). The European Dimension in Higher Education: A Historical Analysis. A paper presented on the international conference "The Relationship between Higher Education and the Nation-State", 7-9 April 1997, Enschede.

Ngome, C. (2003). 'Kenya'. In T. Damtew \& P. G. Altbach (Eds.), African Higher Education: An International Reference Handbook (pp. 359-371). Bloomington: Indiana University Press. Ogachi, O. I. (2011). $21^{\text {st }}$ Century 'Academic Imperialism', Internationalisation of Higher Education and Threats to Indigenization of Research and Innovation for Development in African Universities. A paper presented on the $13^{\text {th }}$ CODESRIA General Assembly: 5-9 December 2011, Rabat, Morocco. Sawyerr, A. (2004). African Universities and the Challenges of Research Capacity Development. Journal of Higher Education Area, 2(1), 211-240.

Scott, P. (1998). Massification, Internationalisation and Globalization. In P. Scott (Ed.), The

Globalization of Higher Education. Buckingham: SRHE and Open University Press.

Sichone, O. (2006). Globalization and Internationalisation of Higher Education in South Africa: The Challenge of Rising Xenophobia. JHEA/RESA, 4(3), 33-53.

Sy Habib, J. (2003). Partnership in Higher Education in Africa: Communications Implications Beyond the 200os. Africa and Asian Studies, 2(4), 577-610.

Teichler, U. (2004). The Changing Debate on Internationalisation of Higher Education. Higher Education, 48(1), 5-26. 
Teichler, U. (1999). Internationalisation as a Challenge for Higher Education in Europe. Tertiary Education and Management, 5, 5-23.

Teklu A. (2008). Education System in Sub-Saharan Africa: Trends and Developments. A paper presented on the Norwegian Agency for Quality Assurance in Education (NOKUT) Annual Seminar on 13-14 October 2008.

University World News. (2014). International Collaboration in African Research - Who Wins? 10 February 2014.

University World News. (2014). International HE Associations Call for Global Equity. 23 January 2014. University World News. (2014). Internationalisation - A student-Centred Approach is Key. 20 April 2014 .

World Bank. (2000). Entering the $21^{\text {st }}$ Century: World Development Report. New York: Oxford University Press.

World Bank. (2002). Constructing Knowledge Societies: New Challenges for Tertiary Education. Washington, DC.

World Population Review. African Population 2014. Retrieved February 102014 from http:// worldpopulationreview.com/continents/africa-population/

Zeleza, P. T. (2012). Internationalisation in Higher Education: Opportunities and Challenges for the Knowledge Project in the Global South. Essay written for keynote address, for the conference A SARUA Leadership Dialogue on Building Capacity of Higher Education to Enhance Regional Development, Maputo, Mozambique, March 21-22, 2012.

\section{Biographical note}

Sintayehu Kassaye Alemu has studied BA and MA in History at Addis Ababa University (Ethiopia), MA in General Education in UMEA University (Sweden), and MPhil in Higher Education in Oslo University (Norway), Tampere University (Finland), and Aviero University (Portugal). Sintayehu has published books and articles and participated in institutional, national, and international conferences. His research interest includes history, education, and Higher Education. At present (2013-2016), Sintayehu is a UNIKE PhD fellow at the University of Ljubljana, Faculty of Education working on internationalization of higher education. 